\begin{tabular}{|c|c|c|}
\hline Beitr. Ent. & Keltern & ISSN 0005-805X \\
\hline $\mathbf{5 6}(2006) 2$ & S. 404 & 15.12 .2006 \\
\hline
\end{tabular}

\title{
Ecology and distribution of ground beetles in an isolated forest ecosystem of Medvednica Mountain
}

\author{
Lucija Šerić Jelaska and Paula Durbešić
}

\begin{abstract}
Summary
The objective of the study was to determine the assemblage of carabids on the centre profile of Medvednica mountain, and their distribution in different forest communities according to various ecological factors: numbers of plant species, altitude, slope, aspect, soil acidity, canopy openness, leaf area index, flow accumulation potential, $\mathrm{Pb}, \mathrm{Cd}, \mathrm{Zn}, \mathrm{Cu}, \mathrm{Ca}$ concentrations and portion of soil organic matter. Ground beetles were sampled by pitfall traps on six plots that were vertically distributed, from bottom to top of the mountain on southern and northern slopes. For calculating biodiversity and habitat preferences according to available ecological factors, diversity indices were calculated, and RDA analyses was performed respectively. 43 species of carabids were recorded, with great differences in species richness and number of their specimens between plots. The greatest biodiversity was recorded for plot placed in Chrysanthemo macrophylli-Aceretum pseudoplatani forest community (according to Shannon-Wiener index $=3,7$ ) and the lowest for plot placed in Luzulo - Fagetum sylvaticae $(2,7)$ with the lowest $\mathrm{pH}$ and plant species diversity. Cluster analyses revealed differences in carabid assemblage between southern and northern slope of Medvednica. Some species like Carabus convexus, Notiophilus rufipes and Carabus intricatus were found exclusively on southern slope of mountain, in contrary to Carabus irregularis, Notiophilus biguttatus, Molops elatus, Platyderus rufus and all of the collected species of the genus Pterostichus recorded exclusively on northern parts of mountain. Among all analysed ecological factors, temperature, soil acidity and plant species richness had the greatest influence on spatial distribution of carabids across investigated area.
\end{abstract}

\section{Zusammenfassung}

Ziel der Arbeit war es, Carabiden aus einer Aufsammlung am zentralen Profil des Medvednica Gebirges zu bestimmen und ihr Vorkommen in unterschiedlichen Forstgesellschaften abhängig von verschiedenen ökologischen Faktoren, wie Anzahl der Pflanzenarten, Höhe über NN, Hangneigung, Himmelsrichtung, pH-Wert des Bodens, Kronendichte, Blattflächenindex, Abfluss-Konzentrations-Potenzial, Pb-, Cd-, Zn-, Cu-, CaKonzentration und Gehalt des Bodens an organischer Substanz zu dokumentieren. Laufkäfer wurden mit je 6 an einem Süd- und einem Nordhang vertikal zwischen Gipfel und Basis des Gebirges verteilten Bodenfallen gesammelt. Zur Berechnung der Biodiversität und der Habitatbindung in Abhängigkeit der ermittelten ökologischen Faktoren wurden Indizes berechnet und RDA-Analysen durchgeführt. Es wurden 43 Arten von Carabiden festgestellt. Zwischen den Proben variierten Artenreichtum und Individuenzahl stark. Die höchste Biodiversität wurde für die in einer Chrysanthemo macrophylli - Aceretum pseudoplatani-Forstgesellschaft gelegene Probefläche (Shannon-Wiener Index = 3,7) festgestellt. Die niedrigste für einen Luzulo - Fagetum sylvaticae-Biotop (2,7), der auch durch den niedrigsten $\mathrm{pH}$-Wert und die geringste Pflanzendiversität charakterisiert war. Cluster-Analysen entdeckten Differenzen zwischen den Carabidenproben vom Nord- und Südhang des Medvednica. Einige Arten, wie Carabus convexus, Notiophilus rufipes und Carabus intricatus wurden ausschließlich am Südhang gefangen. Im Gegensatz dazu wurden Carabus irregularis, Notiophilus biguttatus, Molops elatus, Platyderus rufus und alle Pterostichus-Arten ausschließlich am Nordhang gesammelt. Unter allen analysierten ökologischen Faktoren hatten die Temperatur, der pH-Wert des Bodens und der Reichtum an Pflanzenarten den größten Einfluss auf die räumliche Verteilung der Laufkäfer im Untersuchungsgebiet.

Author's address: Lucija Šerić Jelaska and Paula Durbešić, Department of Zoology, Faculty of Science University of Zagreb, Rooseveltov trg 6, 10000 Zagreb, Croatia 